\title{
Keys To Improving Economic Performance At The Business Unit Level: Business Strategy, Functional Skitls aND KeY Success Factors
}

\author{
James J. Chrisman \\ Louisiana State University \\ Baton Rouge, Louisiana \\ William R. Boulton \\ Auburn University \\ Auburn, Alabama
}

Strategy is generally described in terms of the fit between an organization and its environment [3]. Strategy evaluation typically includes the analysis of this fit in terms of the firm's internal strengths and weaknesses and the opportunities and threats of its external environment [46]. The quality of the resulting strategic fit is argued to affect a firm's economic performance ([27], [38], [33], [48]). Leading theorists further argue that at the business level, a firm's skills and distinctive competences are the key building blocks of strategy ([27], [36]) and that strengths in different types of skills are needed to effectively pursue different types of strategies ([32], [33], [35]). Even though both the levels and types of competitive skills are considered important to the economic success of a strategy [28], few studies have considered them simultaneously in support of this contention.

Researchers have studied strategy-performance relationships in terms of competitive environments ([23], [42], [15], [11], [16], [2], [49]), competitive positions ([39], [14], [50], [13]), and key functional policy decisions ([18], [9], [12], [29]). These studies concentrated on how such variables affect the scope component of competitive strategies, the investment component of business strategies, and the firm's economic performance. While verifying the importance of the environment in formulating effective business strategies and supporting the notion that sustainable competitive advantages are related to superior performance, these studies have not identified how internal functional skills affect business-level performance.

Studies investigating the relationships among strengths and weaknesses, strategies, and firm performance ([10], [19], [20], [21], [22]), have generally supported the work of earlier theorists ([40], [3], [27]). They have, however, almost without exception, concentrated on corporate-level strategy issues. The only business-level studies conducted to date have investigated the relationships between functional strengths and strategies, strengths and performance, and strategies and performance ([6], [41], [43]). There have been no business level studies though that have investigated how a firm's functional skills moderate strategy-performance relationships. Because corporate performance depends on the performance of individual business units [24], studies investigating the relationships between strategies, functional skills, and performance at the business-level are clearly needed. Such a study must also account for the external factors already found to have relationships with strategy and performance. 
To fill this gap, this article explores the relationships between competitive strategy, functional skills, key success factors, and economic performance at the business unit level. The study analyzes 27 firms from six industries using what Harrigan [17] called a medium-grained research methodology. It is an attempt to build theory and test the broad premise of strategic management that economic success is related to the fit between a business strategy and the competitive skills used to meet the key success factors of an industry. The research questions central to this study are:

1. Is a business unit's overall competences in its functional skills related to its economic performance?

2. Is the fit between a business unit's competitive strategy, its dominant functional skills, and its industry's key success factor related to its economic performance?

The lack of research and mid-level theories concerning the relationships between competitive business strategies, functional skills, and economic performance make hypothesis testing impractical for this study. There are classification systems for business strategy [5], skills [35], and key success factors [31], but few, if any, adequate propositions concerning the combinations of skills and key success factors required for a particular strategy to achieve superior economic performance. It is the intent of this study to generate such propositions.

\section{Conceptual Framework \& Language}

The conceptual framework used in this study (Figure 1) can be described as follows. Since strategy represents the fit between an organization's functional skills and the key success factors in its competitive environment ([24], [27], [38], [32]), a business unit's choice of strategy should be influenced by the nature of its functional skills vis-a-vis those skills that are critical to success in its chosen domain of operations. The competitive strength of such skills should further determine the effectiveness of this strategy in achieving an advantageous competitive position and superior economic performance ([3], [24], [27], [1], [32]).

\section{Functional-Area Skills}

This study identified the skills that form the basis for competitive strategy, and may provide an organization with its competitive advantages. Functional skills include the tasks a firm performs in creating, producing, distributing, and marketing its products or services. Thus, four types of functional skills are used in this study: research and development (R\&D), manufacturing, distribution, and marketing ([4], [44], [27]). A business unit's dominant skill is defined as the functional skill that it performs better than any of its other functional skills. We use the concept of dominant skill to supplement the concept of distinctive competence [40] because not every firm has a competence so distinctive that it provides it with a competitive advantage ([3], [27], [41]). By contrast, a dominant skill is the key functional skill upon which the business unit 
has based its strategy. By definition, every firm has a dominant skill whether or not it provides a basis for competitive advantage.

Figure 1: Conceptual Framework

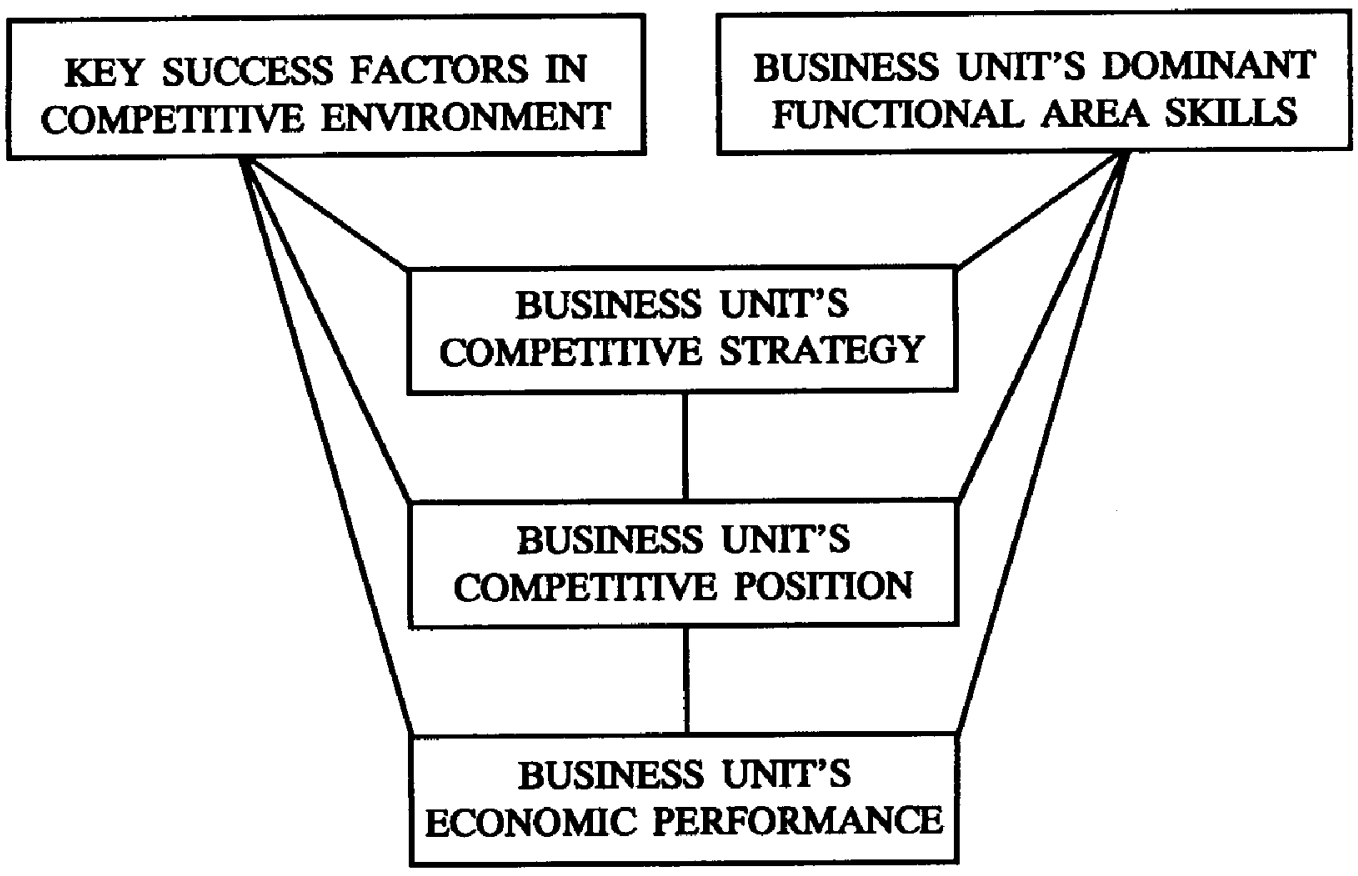

The Competitive Environment

How does an industry's environmental context determine if a firm's functional skills and strategy provide it with sustainable competitive advantages? Most authors would suggest that strategy evaluation must compare the business unit's dominant skills or distinctive competences with its industry's key success factors to determine whether it can develop competitive advantages ([46], [4], [3], [24], [27], [36], [32], [31]). The term "key success factor" denotes the functional skill that is considered critical to success in an industry [31] even though other skills might be more important in certain segments of an industry. Research has shown that business performance is related to a firm's ability to develop strengths in areas that are key to success in its industry [43]. For the purpose of this study, the four functional skills used to classify and identify the key success factor in each industry are research and development, manufacturing, marketing, and distribution.

\section{Competitive Strategies}

Business strategies determine the fit between an organization's dominant functional skills and competences (i.e., corresponding strengths and weaknesses) and the key 
success factors in its competitive environment (i.e., corresponding opportunities and threats) as it pursues its objectives [27]. Realized strategies are, of course, the fit that actually is achieved [30]. Business strategies consist of three substrategies (investment, competitive, and political) which describe the nature of the strategic fit with the industry ([24], [27]). Competitive strategies describe how resources are committed to functional skills and used to attain competitive advantages in the industry.

Competitive strategies consist of three primary components: scope, segment differentiation, and competitive weapons ([1], [33]). Consistent with the work of Chrisman, Hofer, and Boulton [5], this study integrates the generic strategy classification schemes developed by Abell (differentiated, undifferentiated, and focus) and Porter (cost leadership, differentiation, and focus) to account for all three components of strategy. Both Abell's and Porter's schemes are described below.

According to Abell [1], a business can be defined by the scope of its offerings and the extent to which its offerings are differentiated across market segments. Business definition, therefore, consists of both the scope and segment differentiation components of strategy. At the business level scope can be described by the number and breadth of the total product-market segments a company serves in an industry. Segment differentiation describes the extent to which an organization tailors its products, services, or operating methods (competitive weapons) to meet the unique needs of the various segments its serves. Using the terminology of Chrisman, Hofer, and Boulton [5], Abell's three types of business definition strategies have been adapted for this study as follows: mass-market businesses have broad scopes and use the same competitive weapons in all product-market segments they serve; segmented businesses also have broad scopes, but use different competitive weapons to serve different product-market segments; focused or niche-oriented businesses target only one or a few of the product-market segments in an industry.

Competitive weapons refer to the way in which a business unit's functional skills are used to meet customer needs and combat rivals. Porter's [32] differentiation strategy is based on the use of benefit-oriented weapons appealing primarily to the noneconomic needs of buyers. In this study, this strategy will be referred to as a benefit strategy. Porter's cost leadership strategy is based on the use of cost-oriented weapons appealing primarily to the economic (price) needs of customers. Utility-oriented weapons refer to the balanced use of both costs and benefits, thereby meeting both economic and non-economic needs of the marketplace. In this study we refer to simultaneous use of cost and benefit weapons as a utility strategy. Although Porter suggests that the majority of firms that attempt to develop a utility strategy based on the use of both cost and benefit weapons end up "stuck-in-the-middle" with no lasting competitive advantage, research has shown that such an attempt can lead to superior economic performance ([11], [7], [47]).

The combination of Abell's business definitions with these three types of competitive weapons yields nine possible generic strategies: (1) focused cost; (2) focused utility; (3) focused benefit; (4) segmented cost; (5) segmented utility; (6) segmented benefit; (7) mass-market cost; (8) mass-market utility; and, (9) mass-market benefit. 


\section{Competitive Position}

A business unit's competitive position will be determined by its ability to develop distinctive competences in its functional skills that fit its industry's key success factors, and the degree to which its strategy effectively exploits and enhances this fit ([3], [27]). Thus, the types of functional skills a business possesses and its level of capability in them should be assessed relative to both its major competitors in the same businesses and its industry's key success factors ([44], [6], [10], [41], [19], [21], [22]).

In this study, the level of competitive skill of a business unit in any functional area will be classified as strong, average, or weak, relative to its major competitors. A business unit's overall level of competitive capability is assessed in terms of its combined capability in its functional skills relative to its major competitors. In the world motorcycle industry, for example, the British competitor, Norton Villiers Triumph (NVT), was competitively weak in all major functional areas. However, NVT's dominant skill was in research and development. Even though R\&D was NVT's dominant skill, Japanese competitors had much greater R\&D strengths. NVT, therefore, had no significant competitive strengths; in other words, it possessed no distinctive competences.

\section{Business Unit Performance}

A business unit's competitive position results from its ability to develop and exploit competences that fit its industry's key success factors through the application of its competitive strategy. The resulting competitive position will determine its economic (financial and market) performance relative to its competitors. Business unit financial performance has been measured in a variety of different ways such as by return on assets (ROA), return on equity (ROE), return on sales (ROS), and return on value added (ROVA), to name but a few [25]. Objective measures were used to determine relative performance where data were available. However, it was also necessary to use subjective measures because business level performance data are much more difficult to obtain than corporate level performance data. Therefore, to compensate for this problem, a business unit's performance was ranked as superior, average, or inferior relative to competition, based on both objective measures and subjective assessments, as discussed below.

\section{Methodology}

To understand the nature of the relationship between competitive strategy, skills and competences, key success factors, and performance, a longitudinal analysis of 27 business units from six different industries was conducted. Both qualitative and quantitative data were collected and analyzed.

\section{Research Design \& Sample Selection}

Hofer [24] argued that the stage of industry evolution is the most fundamental variable for determining an appropriate business-level strategy. He also suggested that 
the introduction, shake-out, and decline might be most strategically important to a business in developing its competitive strategy. Because past studies have supported Hofer's contention on the importance of the stage of an industry's evolution in determining business unit performance ([2], [45]), this criterion was used as the primary basis for sample selection.

Ii selecting the sample for this study, businesses competing in industries in the shake-out, maturity (usually the longest and most prevalent stage observable in an industry's life cycle), and decline stages of evolution were selected. Industries in the introductory stage were excluded after initial analysis showed a lack of sufficient data. For each stage of industry evolution studied, two consumer manufacturing industries were selected: one where buyer needs were considered to be primarily benefit-oriented and one where buyer needs were considered to be primarily cost-oriented [24]. In total, 27 businesses from six industries were studied. Market growth rates and the assessments of industry observers were used to identify each industry's stage of evolution.

To ensure an adequate mix of functional competences amongst the sample, industries were selected that included at least one firm with a dominant skill in R\&D, manufacturing, and marketing or distribution. Descriptions of 24 industries and more than 100 companies, found in a total of 46 casebooks, industry analyses, and research monographs, were thoroughly reviewed to ensure that the industries selected met the research design criteria. Table 1 lists the six industries and 27 businesses included in this study as well as the time periods over which they were analyzed.

Table 1: Industries \& Businesses Selected for the Study

SHAKE OUT

MATURITY

DECLINE

\begin{tabular}{|l|l|l|}
\hline Personal Computers & Motorcycles & Receiving Tubes \\
1980-1985 & $1967-1975$ & $1967-1978$ \\
Apple & BMW & General Electric \\
Commodore & Harley-Davidson & GTE Sylvania \\
IBM & Honda & RCA \\
Osborne & Norton Villiers & \\
Tandy & & \\
Texas Instruments & & \\
& & \\
\hline
\end{tabular}


Table 1: Industries \& Businesses (Continued)

SHAKE OUT

MATURITY

DECLINE

\begin{tabular}{|l|l|l|}
\hline Writing Instruments & Watches & \multicolumn{1}{c|}{ Cigars } \\
\hline $1968-1973$ & $1968-1973$ & $1964-1978$ \\
& Bulova & American Cigar \\
Bic Pen & Hamilton Watch & Bayuk Cigar \\
Gillette & Seiko & Consolidated Cigar \\
Scripto & The Swiss & Culbro \\
& Timex & Havatampa \\
& & Jno. H. Swisher \\
& & \\
\hline
\end{tabular}

\section{Data Gathering Methods}

A total of 119 secondary sources of information, including previously published case studies, articles in business periodicals and books, company documents, and reference books were content analyzed to obtain data for the study. General information about each industry and company was collected, as well as published statements from industry analysts concerning industry key success factors, functional skills, and business strategies ([17], [34], [37]). Data covering periods ranging from ten to twenty years for each business and industry were initially collected. However, strategies, skills, and industry key success factors can change over time. Therefore, each industry and company was analyzed over time periods of five to fifteen years during which key success factors, dominant skills, and strategies remained relatively stable. If more than one time period was usable, the time period with the best quality data was selected.

Initial analysis did not suggest that differences in time periods or economic cycles influenced the results of this study. A subsequent test using different time periods for a subsample of eight business units from two industries further supported this assumption.

\section{Measurement Issues \& Techniques}

Detailed case descriptions of each industry and its competing business units were developed. The cases included data on the key success factors of each industry, as well as the functional skills, strategies, and performance of each business unit. The cases averaged over 40 pages in length. Published reports by industry analysts were critical for identifying industry key success factors, business strategies, functional skills and competences, and performance. Comparative variables, including performance, were determined by ranking the competitors. Performance evaluations were made independently after all other variables were measured to minimize the possibility of rating bias.

To ensure the measurement reliability of key success factors, dominant skills and distinctive competences, and competitive strategies, a two stage procedure was followed. 
First, the two researchers independently evaluated the cases and classified the variables of interest. Their interrater agreement was $\mathbf{8 8 . 9}$ percent. Additional research resolved the few discrepencies that occurred. Second, a panel of seven doctoral students independently reviewed the detailed cases and completed data evaluation forms. While one member of the panel evaluated all six industries, the remaining six panelists evaluated three industries each. Therefore, a total of four judges independently identified each industry's key success factor, and the strategies, functional skills, and performance of each business unit. Overall agreement between raters on all these evaluations was 75.9 percent, as shown in Table 2. Further discussion helped to attain final consensus in cases where raters disagreed.

Table 2: Degree Of Agreement of the Evaluations of the Panel With the Evaluations of the Researchers on the Variables of Interest By Industry

\begin{tabular}{|c|c|c|c|c|c|}
\hline & $\begin{array}{l}\text { Key Succ- } \\
\text { ess Factor }\end{array}$ & $\begin{array}{l}\text { Dominant } \\
\text { Skill }\end{array}$ & $\begin{array}{l}\text { Business } \\
\text { Strategy }\end{array}$ & $\begin{array}{l}\text { Economic } \\
\text { Performance }\end{array}$ & $\begin{array}{l}\text { Total Interrat } \\
\text { Agreement }\end{array}$ \\
\hline $\begin{array}{l}\text { Personal } \\
\text { Computers } \\
\text { (6 firms) }\end{array}$ & $\begin{array}{l}3 \text { of } 4 \\
(75.0 \%)\end{array}$ & $\begin{array}{l}23 \text { of } 24 \\
(95.8 \%)\end{array}$ & $\begin{array}{l}17 \text { of } 24 \\
(70.8 \%)\end{array}$ & $\begin{array}{l}19 \text { of } 24 \\
(79.2 \%)\end{array}$ & $\begin{array}{l}62 \text { of } 76 \\
(81.6 \%)\end{array}$ \\
\hline $\begin{array}{l}\text { Writing } \\
\text { Instruments } \\
\text { (3 firms) }\end{array}$ & $\begin{array}{l}3 \text { of } 4 \\
(75.0 \%)\end{array}$ & $\begin{array}{l}11 \text { of } 12 \\
(91.7 \%)\end{array}$ & $\begin{array}{l}10 \text { of } 12 \\
(83.3 \%)\end{array}$ & $\begin{array}{l}12 \text { of } 12 \\
(100.0 \%)\end{array}$ & $\begin{array}{l}36 \text { of } 40 \\
(90.0 \%)\end{array}$ \\
\hline $\begin{array}{l}\text { Motorcycles } \\
\text { (4 firms) }\end{array}$ & $\begin{array}{r}2 \text { of } 4 \\
(50.0 \%)\end{array}$ & $\begin{array}{l}11 \text { of } 16 \\
(68.8 \%)\end{array}$ & $\begin{array}{l}14 \text { of } 16 \\
(87.5 \%)\end{array}$ & $\begin{array}{r}10 \text { of } 16 \\
(62.5 \%)\end{array}$ & $\begin{array}{l}37 \text { of } 52 \\
(71.2 \%)\end{array}$ \\
\hline $\begin{array}{l}\text { Watches } \\
\text { (5 firms) }\end{array}$ & $\begin{array}{l}3 \text { of } 4 \\
(75.0 \%)\end{array}$ & $\begin{array}{l}14 \text { of } 20 \\
(70.0 \%)\end{array}$ & $\begin{array}{l}17 \text { of } 20 \\
(85.0 \%)\end{array}$ & $\begin{array}{l}16 \text { of } 20 \\
(80.0 \%)\end{array}$ & $\begin{array}{l}50 \text { of } 64 \\
(78.1 \%)\end{array}$ \\
\hline $\begin{array}{l}\text { Receiving } \\
\text { Tubes } \\
\text { ( } 3 \text { firms) }\end{array}$ & $\begin{array}{l}3 \text { of } 4 \\
(75.0 \%)\end{array}$ & $\begin{array}{l}12 \text { of } 12 \\
(100.0 \%)\end{array}$ & $\begin{array}{l}4 \text { of } 12 \\
(33.3 \%)\end{array}$ & $\begin{array}{l}8 \text { of } 12 \\
(66.7 \%)\end{array}$ & $\begin{array}{l}27 \text { of } 40 \\
(67.5 \%)\end{array}$ \\
\hline $\begin{array}{l}\text { Cigars } \\
\text { (6 firms) }\end{array}$ & $\begin{array}{l}4 \text { of } 4 \\
(100.0 \%)\end{array}$ & $\begin{array}{l}18 \text { of } 24 \\
\text { (75.0\%) }\end{array}$ & $\begin{array}{l}15 \text { of } 24 \\
(62.5 \%)\end{array}$ & $\begin{array}{l}15 \text { of } 24 \\
(62.5 \%)\end{array}$ & $\begin{array}{l}52 \text { of } 76 \\
(68.4 \%)\end{array}$ \\
\hline $\begin{array}{l}\text { TOTAL } \\
\text { INTERRATER } \\
\text { AGREEMENT }\end{array}$ & $\begin{array}{l}18 \text { of } 24 \\
(75.0 \%)\end{array}$ & $\begin{array}{c}89 \text { of } 108 \\
(82.4 \%)\end{array}$ & $\begin{array}{c}77 \text { of } 108 \\
(71.3 \%)\end{array}$ & $\begin{array}{l}80 \text { of } 108 \\
(74.1 \%)\end{array}$ & $\begin{array}{l}264 \text { of } 348 \\
(75.9 \%)\end{array}$ \\
\hline
\end{tabular}




\section{Functional Skills}

The functional skill that the organization performed better than any other was considered its dominant skill and was rated as strong, average, or weak. Interrater agreement on the dominant skills of the 27 businesses analyzed was 82.4 percent.

Each business unit's overall competence in the four functional areas studied were then analyzed relative to major competitors and rated as strong, average or, weak. All functional areas were weighted equally to obtain the business unit's level of overall functional competences. Rater assessments yielded consistent results in 82.4 percent of the cases. Additional research was conducted to resolve the discrepancies in the cases where the evaluations did not agree.

\section{Key Success Factors}

The key success factor for each industry was determined from published reports of recognized industry analysts. Their reviews described the importance of the various functional skills for an industry as a wnole and for particular product-market segments of the industry. The observations of industry experts were generally consistent. Overall interrater agreement between the panel and researchers on the key success factors in the six industries included in this study was 75 percent.

\section{Competitive Strategies}

Competitive strategies were evaluated in terms of scope, segment differentiation, and competitive weapons. Scope measures the extent of a business unit's productmarket coverage and segment differentiation measures the number and type of competitive weapons used across served product-market segments. For example, a business unit with broad scope that competed in the same way across all major segments served was considered to follow a mass-market strategy. A business unit with broad scope that varied its approaches across segments served was considered to follow a segmented strategy. A business unit that served only one or a few small segments of the market, had a narrow scope, and, thus, was considered to follow a focused strategy.

Competitive weapons were distinguished using Porter's [32] criteria for classifying cost leadership and differentiation (benefit) strategies. The relative costs, prices, and benefits of the competing products and services offered by each business unit were examined. For example, a business with lower-priced products of average quality followed a cost strategy, a business with higher-priced products of high quality followed a benefit strategy, and a business with lower-priced products of high quality followed a utility strategy.

The proportions of each business unit's activity in low, medium, and high priced segments were also considered. If, for instance, the business unit's major source of sales revenues came from lower priced products, it was considered to follow a cost strategy. Where possible, both methods of assessment were used and tended to yield consistent results. In all, the panel agreed 71 percent of the time with the researchers' identification of the competitive strategies of the sample. 


\section{Economic Performance}

A business unit's economic performance was rated as superior, average, or inferior in relation to its major competitors. To the extent possible, evaluations were based on the actual financial (ROE, ROS, ROA) and market share data. However, for slightly more than half of the business units studied, the performance data used were qualitative. In these instances, performance data were determined from reports and observations of industry analysts and executives. Dess and Robinson [8] showed that such subjective measurements, although less desirable than objective measures, are reasonably accurate. In fact, the quantitative and qualitative performance evaluations were consistent in almost 80 percent of the cases where both types of data were available. The performance evaluations of the panel were consistent in almost $75 \%$ of the cases with the researchers' assessments.

\section{Data Analysis Techniques}

Nominal and ordinal business unit data were cross-tabulated and analyzed in a variety of ways. Patterns of successful strategies and functional skills, key success factors, and performance were identified. The strongest patterns were statistically tested using the chi-square, Kruskal-Wallis, and Wilcoxon rank-sum nonparametric tests. Small sample sizes, the ordinal nature of the data, and non-normal distributions prevented the use of parametric statistics. Tests were used to investigate the research questions described earlier as well as to generate specific propositions on strategy-skillperformance relationships.

\section{Analysis \& Results}

Is a business unit's overall competences in its functional skills related to its economic performance?

The first research question compared a business unit's level of overall functional competences, relative to competitors, with its economic performance. Not unexpectedly, the level of a business unit's overall competences was found to be positively related to its performance (Table 3). The performance of almost 80 percent of the business units in the sample was consistent with their overall competences, a result significantly different from chance $(p<.001)$. 
Table 3: Relationships Between the Overall Strengths of a Business Unit and Its Economic Performance

ECONOMIC PERFORMANCE

Superior Average Inferior

RELATIVE

OVERALL

STRENGTHS

\begin{tabular}{|c|c|c|c|}
\hline & Superior & Average & Inferior \\
\hline Strong & $8^{*}$ & 3 & 0 \\
\hline Average & 0 & $6^{*}$ & 3 \\
\hline Weak & 0 & 0 & $7^{*}$ \\
\hline
\end{tabular}

*Correct Predictions: 21 of 27 (78\%)

Chance Predictions: 9 of 27 (33\%)

Chi-square goodness-of-fit test (d.f. $=1)=24.0(p<.001)$

A Kruskal-Wallis test provided additional support for this conclusion. Significant differences were found in the performance of businesses with strong, average, and weak overall competences in their functional skills $(p<.001)$. Multiple comparisons of the three groups using the Wilcoxon rank-sum test revealed significant performance differences between businesses with strong and weak $(p<.01)$, strong and average $(p$ $<.01$ ), and average and weak $(p<.05)$, overall competences.

Is the fit between a business unit's competitive strategy, its dominant functional skills, and its industry's key success factor related to its economic performance?

The matrix shown in Figure 2 shows the competitive strategies, dominant functional skills, industry key success factors, and relative economic performance of the business units included in this study. Each business unit is positioned in the matrix according to its industry's key success factor and the type of dominant functional skill it possessed. Its strategy (e.g., $\mathrm{SB}=$ segment benefit) and economic performance (e.g., $0=$ average performance) are also denoted. Strategies and economic performance of the business units were then analyzed according to their positions in the matrix. 
Figure 2: Competitive Strategies, Key Success Factors, Domingnt Skills, and Economic Performance Of Consumer Products Manufacturers*

KEY SUCCESS FACTORS

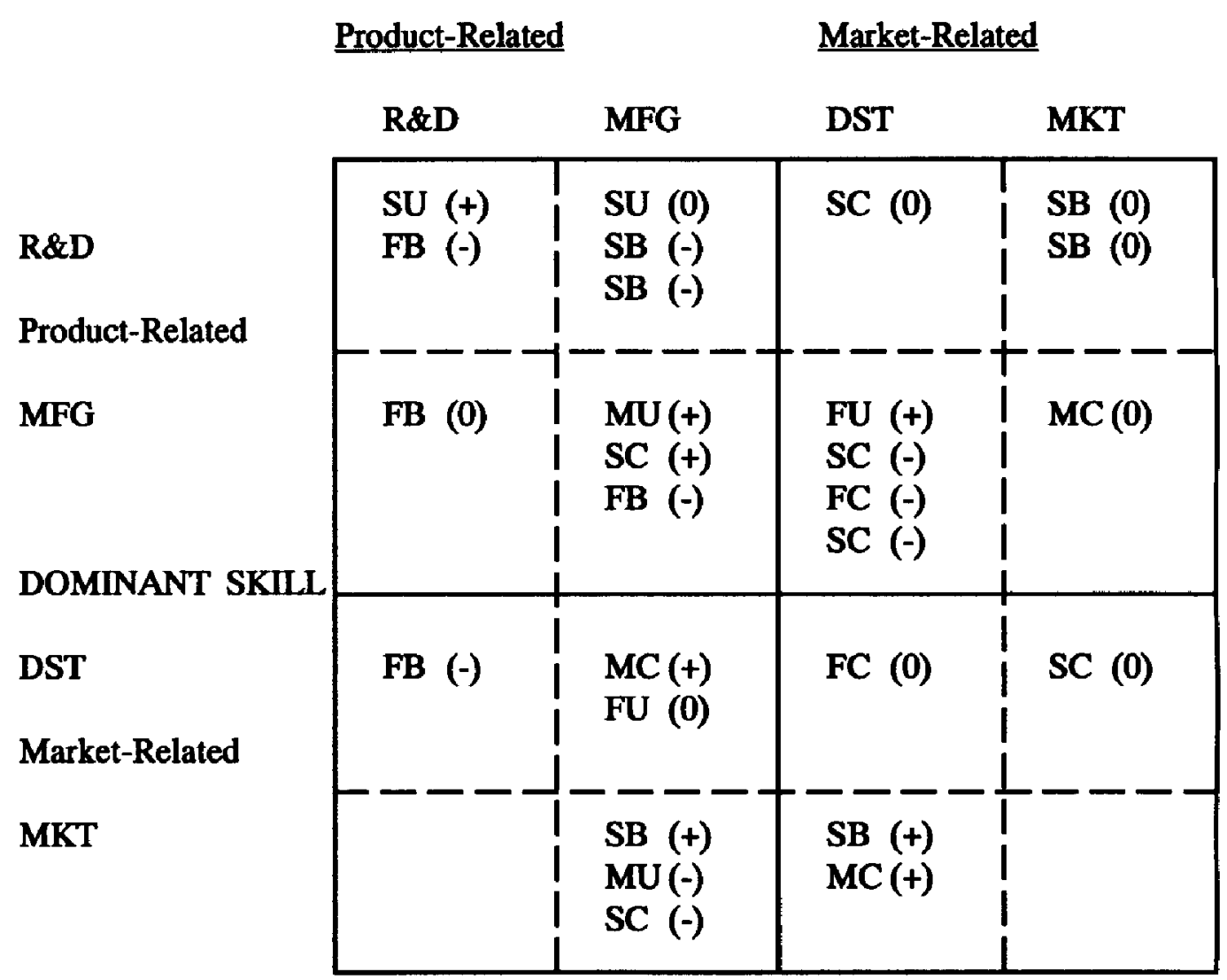

*Economic Performance: $(+)=$ Superior, $(0)=$ Average, $(-)=$ Inferior

Competitive Strategy: $\mathbf{S}=$ Segmented, $F=$ Focused, $\mathbf{M}=$ Mass-market, $\mathbf{B}=$ Benefit, $\mathbf{U}=\mathbf{U}$ Utility, $\mathbf{C}=$ Cost

Dominant Skills: R\&D = Research \& Development, MFG = Manufacturing, MKT = Marketing, DST = Distribution

The 16 cell matrix created small cell counts and made it difficult to find meaningful relationships. However, patterns within the matrix suggested that successful business units with dominant skills in product-related functions (i.e., R\&D or manufacturing) used different competitive strategies from than less successful firms, and from the successful firms with dominant skills in market-related functions (i.e., marketing or distribution). Likewise, successful firms with dominant skills in market-related functions used somewhat different strategies than their less successful counterparts. The same held true when analyzing strategies and performance according to industry key success factors. These observations suggested that the matrix might be collapsed into product-related and market-related cells for further analysis. This simplified matrix 
allowed the analysis of larger sample sizes per cell. The simplified matrix is composed of four cells distinguished by the solid lines in Figure 2.

\section{Relationships Between Strategies And Key Success Factors}

No strategies were found to be superior or inferior to other strategies in all situations. Analysis of the simplified matrix indicated, however, that a strategy's success was related to the key success factor in an industry. The Wilcoxon rank-sum test indicated that in industries where the key success factor was product-related, benefit strategies were significantly less successful than utility and cost strategies $(p<.05)$. In fact, out of the six firms following benefit strategies, five (83\%) experienced inferior performance vis-a-vis their major competitors. By contrast, all four firms employing utility strategies achieved at least average performance (50\% achieved superior performance) and both of the firms following cost strategies attained superior performance. The inferior performance of the benefit strategies was particularly apparent when the businesses following those strategies had a product-related dominant skill.

Benefit strategies were significantly more successful in industries where the industry key success factor was market-related rather than product-related $(p<.05)$. Benefit strategies also appeared more successful than cost strategies in industries with market-related key success factors, although the differences in performance were not statistically significant. Out of the nine business units following cost strategies in such industries, four (44\%) experienced inferior performance, four $(\mathbf{4 4 \% )}$ ) were average performers, and only one (11\%) achieved superior performance. By contrast, two of the four businesses (50\%) following benefit strategies in those industries achieved superior performance and two (50\%) experienced average performance.

\section{Relationships Between Strategies And Dominant Skills}

Analysis of the simplified four-cell matrix also suggested that a strategy's success was related to the dominant skill of the business (Figure 2). The Wilcoxon rank-sum test indicated that business units following utility strategies significantly outperformed those that followed cost or benefit strategies when the dominant skill was productrelated $(p<.05)$. Thus, three of the four businesses $(75 \%)$ following utility strategies achieved superior performance while only one of the six businesses (17\%) following cost strategies, and none of the seven ( $0 \%$ ) following benefit strategies were able to do so. In fact, over half of the businesses following cost or benefit strategies experienced inferior performance relative to their major competitors. Cost strategies, however, did seem to lead to slightly more favorable performance than benefit strategies for businesses with dominant skills in product-related functions, but this finding was not statistically significant.

No strategies were found to be statistically superior for businesses with dominant skills in market-related functions. The utility strategies of the two businesses with dominant skills in market-related functions yielded average and inferior performance. On the other hand, two of the three businesses (67\%) that followed benefit strategies achieved superior performance. Cost strategies also appeared to provide prospects for 
at least average performance. Among the five firms following cost strategies, two were superior performers (40\%), two were average performers (40\%), and one $(20 \%)$ was an inferior performer.

\section{Competitive Strategy Propositions}

Results indicate that successful strategies are related to both the dominant functional skill of a business unit and the key success factor of its industry. To further test such relationships, the propositions shown in Figure 3 were developed from the findings shown in Figure 2 and described above. These propositions suggest what should be the best, next best, and worst strategies for a business depending on its dominant skill and the key success factor in its industry. The rationale for these propositions is summarized as follows:

\section{Figure 3: Competitive Strategy Propositions*}

KEY SUCCESS FACTORS

\begin{tabular}{|c|c|c|c|c|}
\hline & \multicolumn{2}{|c|}{ Product-Related } & \multicolumn{2}{|c|}{ Market-Related } \\
\hline & R\&D & MFG & DST & MKT \\
\hline & SECTOR 1 & & SECTOR 2 & \\
\hline R\&D & Best Strategy: & UTILITY & Best Strategy: & UTILITY \\
\hline Product-Related & Next Best: & COST & Next Best: & BENEFIT \\
\hline MFG & Worst Strategy: & BENEFIT & Worst Strategy: & Cost \\
\hline DOMINANT SKILL & SECTOR 3 & & SECTOR 4 & \\
\hline DST & Best Strategy: & COST & Best Strategy: & BENEFIT \\
\hline Market-Related & Next Best: & UTILITY & Next Best: & COST \\
\hline MKT & Worst Strategy: & BENEFIT & Worst Strategy: & UTILITY \\
\hline
\end{tabular}

*ECONOMIC PERFORMANCE PREDICTION:

Best Strategy = Superior Performance

Next Best = Average Performance

Worst Strategy $=$ Inferior Performance

(1) Business units following the best strategy will usually achieve superior performance,

(2) Business units following the next best strategy will usually achieve average performance, and,

(3) Business units following the worst strategy will usually achieve inferior performance. 
For example, according to the propositions in Sector 1 of Figure 3, a business with a dominant skill in a product-related function (R\&D or manufacturing rows) that competes in an industry where product-related skills are key to success should be most successful using a utility strategy and least successful using a benefit strategy. In the same vein, a cost strategy should result in average performance. As shown in Table 4 , a chi-square goodness-of-fit test indicated that in almost $75 \%$ (20 of 27 ) of the cases, performance predictions derived from the propositions shown in Figure 3 proved correct, a result significantly different from chance $(p<.001)$.

Table 4: Competitive Strategies as Predictors of Business Unit Economic Performance

ECONOMIC PERFORMANCE

Superior Average Inferior

$\begin{array}{ll}\text { APPROPRIATENESS } & \text { Best } \\ \text { OF STRATEGY } & \\ \text { SELECTED GIVEN } & \\ \text { DOMNANT SKILL } & \text { Next Best } \\ \text { AND KEY SUCCESS } & \\ \text { FACTOR } & \end{array}$

Worst

\begin{tabular}{|c|c|c|}
\hline $6^{*}$ & 1 & 0 \\
\hline 2 & $5^{*}$ & 1 \\
\hline 0 & 3 & $9^{*}$ \\
\hline
\end{tabular}

*Correct Predictions: 20 of 27 (74\%)

Chance Predictions: 9 of 27 (33\%)

Chi-square goodness-of-fit test (d.f. $=1)=20.16(p<.001)$

\section{Propositions About Competitive Strategy, Dominant Skills, And Performance}

Propositions provided in Figure 3 explain the variations in the sample's performance almost $75 \%$ of the time. However, since a business unit's relative economic performance will also be influenced by its relative overall competences (Table 3), following the correct strategy will not necessarily generate superior performance if the business unit's skills are weaker than its major competitors' skills. On the other hand, as Figure 3 presumes, an inappropriate strategy can reduce the economic effectiveness of even the strongest firms. A business with superior overall competences that develops an appropriate strategy should be virtually guaranteed superior performance, and one with inferior overall competences and an inappropriate strategy should almost always experience inferior performance. 
To account for both the appropriateness of a business unit's strategy and its overall competences relative to its competitors, the results regarding overall functional competences (Table 3) and business strategy (Table 4) were combined to develop the propositions shown in Figure 4. The actual performance of each business unit was then compared against the performance predicted by the propositions (Table 5). This approach allowed us to test the overall validity of the framework despite the fact that sample sizes were insufficient to individually test each proposition that made up the framework [26]. As Table 5 indicates, the combined framework helped explain the relative economic performance of the entire sample. While there is an obvious bias in using the same data to both develop and test a framework, the strong fit suggests that the propositions have high potential for explaining performance variations among consumer goods manufacturers.

\section{Figure 4: Strategy-Skills-Performance Propositions*}

\section{RELATIVE OVERALL COMPETENCE OF THE BUSINESS**}

STRATEGY***

Strong

Average

Weak

BEST
NEXT BEST

WORST

\begin{tabular}{|c|c|c|}
\hline Superior & Superior or Average & Average or Inferior \\
\hline Superior or Average & Average & Average or Inferior \\
\hline Average & Average or Inferior & Inferior \\
\hline
\end{tabular}

*Given the way the propositions illustrated in this matrix were formulated, performance could be correctly predicted by chance $51.9 \%$ of the time.

**See Table 3

***See Figure 3 and Table 4 
Table 5: Actual Versus Predicted Economic Performance of the Sample of Business Units*

$\begin{array}{lllllll}\text { Company } & \text { DS } & \text { KSF } & \begin{array}{l}\text { Relative } \\ \text { Skills }\end{array} & \begin{array}{l}\text { Business Actual } \\ \text { Strategy Performance }\end{array} & \begin{array}{l}\text { Predicted } \\ \text { Performance }\end{array} \\ \text { IBM } & \text { Mkt } & \text { Mkt } & \text { Strong } & \text { Seg-Ben } & (+) & (+) \\ \text { Bic } & \text { Mkt } & \text { Mkt } & \text { Strong } & \text { MM-Cost } & (+) & (+) /(0) \\ \text { Honda } & \text { R\&D } & \text { R\&D } & \text { Strong } & \text { Seg-Util } & (+) & (+) \\ \text { Timex } & \text { Dst } & \text { Mfg } & \text { Strong } & \text { MM-Cost } & (+) & (+) \\ \text { Seiko } & \text { Mfg } & \text { Mfg } & \text { Strong } & \text { MM-Util } & (+) & (+) \\ \text { GTE Sylvania } & \text { Mfg } & \text { Mfg } & \text { Strong } & \text { Seg-Cost } & (+) & (+) /(0) \\ \text { Consol. Cigar } & \text { Mkt } & \text { Dst } & \text { Strong } & \text { Seg-Ben } & (+) & (+) \\ \text { Swisher } & \text { Mfg } & \text { Dst } & \text { Strong } & \text { Foc-Util } & (+) & (+) \\ \text { Apple } & \text { R\&D } & \text { Mkt } & \text { Average } & \text { Seg-Ben } & (0) & (0) \\ \text { Commodore } & \text { Mfg } & \text { Mkt } & \text { Average } & \text { MM-Cost } & (0) & (0) /(-) \\ \text { Tandy } & \text { Dst } & \text { Mkt } & \text { Average } & \text { Seg-Cost } & (0) & (0) \\ \text { Gillette } & \text { R\&D } & \text { Mkt } & \text { Strong } & \text { Seg-Ben } & (0) & (0) /(+) \\ \text { BMW } & \text { Mfg } & \text { R\&D } & \text { Average } & \text { Foc-Ben } & (0) & (0) /(-) \\ \text { Bulova } & \text { R\&D } & \text { Mfg } & \text { Average } & \text { Seg-Util } & (0) & (0) /(+) \\ \text { General Electr. } & \text { Dst } & \text { Mfg } & \text { Strong } & \text { Foc-Util } & (0) & (0) /(+) \\ \text { Culbro } & \text { R\&D } & \text { Dst } & \text { Strong } & \text { Seg-Cost } & (0) & (0) \\ \text { Havatampa } & \text { Dst } & \text { Dst } & \text { Average } & \text { Foc-Cost } & (0) & (0) \\ \text { Texas Instr. } & \text { Mfg } & \text { Mkt } & \text { Weak } & \text { Seg-Cost } & (-) & (-) \\ \text { Osbome } & \text { Mfg } & \text { Mkt } & \text { Weak } & \text { Foc-Cost } & (-) & (-) \\ \text { Scripto } & \text { Mfg } & \text { Mkt } & \text { Weak } & \text { Seg-Cost } & (-) & (-) \\ \text { Harley-Dav. } & \text { Dst } & \text { R\&D } & \text { Average } & \text { Foc-Ben } & (-) & (-) /(0) \\ \text { NVT } & \text { R\&D } & \text { R\&D } & \text { Weak } & \text { Foc-Ben } & (-) & (-) \\ \text { Hamilton(HMW) } & \text { R\&D } & \text { Mfg } & \text { Weak } & \text { Seg-Ben } & (-) & (-) \\ \text { The Swiss } & \text { Mfg } & \text { Mfg } & \text { Weak } & \text { Foc-Ben } & (-) & (-) \\ \text { RCA } & \text { R\&D } & \text { Mfg } & \text { Average } & \text { Seg-Ben } & (-) & (-) /(0) \\ \text { American Cigar } & \text { Mkt } & \text { Dst } & \text { Average } & \text { MM-Util } & (-) & (-) /(0) \\ \text { Bayuk Cigar } & \text { Mkt } & \text { Dst } & \text { Weak } & \text { Seg-Cost } & (-) & (-) /(0) \\ & & & & & & \end{array}$

*CORRECT PREDICTIONS: 27 of 27 (100\%), CHANCE PREDICTIONS: 14 of 27 (51.9\%). ECONOMIC PERFORMANCE

Superior $=(+)$, Average $=(0)$, Inferior $=(-)$

COMPETITIVE STRATEGIES

Foc $=$ Focused, $M M=$ Mass-Market, Seg $=$ Segmented,

Ben $=$ Benefit, Util $=$ Utility, Cost $=$ Cost.

DOMINANT SKIIL/KEY SUCCESS FACTOR

R\&D = Research \& Development, $\mathbf{M f g}=$ Manufacturing,

Mkt $=$ Marketing, Dst $=$ Distribution 
In sum, the effectiveness of the framework of propositions to predict the economic performance of the sample appears to support the theory of the field. The explanatory power of the propositions shown in the Figure 4 framework was greater than those that considered either a business unit's overall functional competences (Table 3 ) or strategy (Figure 3 and Table 4) separately.

\section{Summary \& Conclusions}

The results of this study further support the conceptual arguments and research of the field of strategic management. Thus this study found that no generic strategy was inherently superior or inferior to other generic strategies. This study also found that successful business units had greater levels of competences in their functional skills than their less successful competitors, as well as strategies that better fit their dominant skills and the key success factors of their industries.

This strongly suggests that superior performance depends upon both a business unit's ability to develop distinctive competences in its functional skills, and the strategy used to achieve fit between its dominant skills and the key success factors of its industry. Neither distinctive competence nor strategy alone was as effective as both combined in predicting the relative economic performance of this sample. Thus, as strategic management theory argues, relative strengths or weaknesses in specific functional skills are important only in the context of the industry environment. It is the way in which a business utilizes these skills to support its strategy that ultimately determines its competitive position and performance.

It is also interesting to note that the effective use of functional skills seems more important than either scope or degree of segment differentiation, since all the significant findings and propositions reported in this study related to the competitive weapons employed. Thus, within a given industry, how a business competes appears to be more important to its relative economic performance than where it competes.

In short, this study confirms the usefulness of the concept of strategy for examining business unit performance, and the primary importance of identifying and developing distinctive competences that may lead to competitive advantage.

\section{Directions For Future Resench}

The findings of this study suggest a line of inquiry that may be generalizable to manufacturers of consumer products. First, the propositions generated from this study should be tested and refined through future research with larger samples. Replications of this study in industrial manufacturing, retail, wholesale, and service businesses are clearly needed as are replications in consumer products industries in other stages of development. Such studies should strive to improve upon the methods of sample selection, data collection, and variable measurements as these areas represent the primary limitations of this exploratoty study.

The development of competitive functional skills proved to be critical to attaining superior economic performance. Therefore, future studies might investigate a number 
of questions related to the nature of strategies needed to utilize, develop, and maintain such competitive capabilities. Is it possible, for example, for a business to effectively change its dominant skill over time, or do initial choices determine, for all practical purposes, its future in any specific industry? If it is possible, how long does it usually take for such changes to pay off? It would also be useful to investigate whether a business, can, or should, change either its strategy, dominant skills, or both when it finds that they do not match the key success factors of its industry.

Similar studies to identify corporate-level competences and strategies that may either influence, or be transferrable to, the business level are also needed, as are studies that relate corporate-level competences and strategies to diversification or innovation options. However, researchers should keep in mind that corporate-level competences are not simply aggregations of business-level competences [44].

Besides these replications and extensions, additional work is needed in improving the systems used for classifying and identifying organizational strategies, functional skills and competences, and various environmental characteristics such as key success factors. The extensive amount of time and attention paid to these areas are believed to have contributed to the generally high level of statistical significance of this study's findings despite its small sample size [36].

\section{Implications For Management Practice}

The findings of this study suggest that the most important challenges for businesslevel managers are (1) to develop distinctive competence in functional skills key to success in their industries, and (2) to formulate strategies that effectively utilize these functional competences. Thus, managers must appreciate the business unit's dominant skills and key success factors in its industry, and deploy the resources necessary to sustain and improve its capabilities in those areas. This suggests that a business will do better with a strategy built on its strengths than a strategy designed to compensate for its weaknesses. In short, managers who understand what their business can do better than its competitors and what skills are most highly valued in the marketplace are much more likely to formulate a strategy which will achieve superior performance than those that do not.

\section{References}

1. Abell, D.F. Defining the Business: The Starting Point of Strategic Planning, PrenticeHall: Englewood Cliffs, NJ (1980).

2. Anderson, C.R., \& Zeithaml, C.P. Stages of the Product Life Cycle, Business Strategy, and Business Performance. Academy of Management Journal, Vol. 27 (1984), pp. 5-24.

3. Andrews, K.R. The Concept of Corporate Stratery, Irwin: Homewood, IL (1971).

4. Ansoff, H.l. Comporate Strategy: An Analytical Approach to Business Policy for Growth and Expansion, McGraw-Hill: New York, NY (1965). 
5. Chrisman, J.J., Hofer, C.W., \& Boulton, W.R. "Toward a System for Classifying Business Strategies." Academy of Management Review, Vol. 13 (1988), pp. 413-428.

6. Comte, T.E. "A Study of the Process of Appraisal of Internal Strengths and Weaknesses As a Strategic Activity in Selected Industries." Unpublished doctoral dissertation, University of Missouri-Columbia (1978).

7. Dess, G.G., \& Davis, P.S. “Porter's (1980) Generic Strategies as Determinants of Strategic Group Membership and Organizational Performance." Academy of Management Journal, Vol. 27 (1984), pp. 467-488.

8. Dess, G.G., \& Robinson, R.B. Jr. "Measuring Organizational Performance in the Absence of Objective Measures: The Case of the Privately-held Firm and Conglomerate Business Unit." Strategic Management Journal, Vol. 5 (1984), pp. 265-273.

9. Galbraith, C., \& Schendel, D. “An Empirical Analysis of Strategic Types." Strategic Management Journal, Vol. 4 (1983), pp. 153-173.

10. Godiwalla, Y.M., Meinhart, W.A., \& Warde, W.D. Corporate Strategy and Functional Management, Praeger: New York, NY (1979).

11. Hall, W.K. "Survival Strategies in a Hostile Environment." Harvard Business Review, Vol. 58 (5), (1980), pp. 75-85.

12. Hambrick, D.C., MacMillan, I., \& Barbosa, R.R. "Business Unit Strategy and Changes in the Product R\&D Budget." Management Science, Vol. 29 (1983), pp. 757-769.

13. Hambrick, D.C., \& Schecter, S.M. "Turnaround Strategies for Mature Industrial-product Business Units." Academy of Management Journal, Vol. 26 (1983), pp. 231-248.

14. Hamermesh, R.G., Anderson, M.J. Jr., \& Harris, J.E. "Strategies for Low Market Share Businesses." Harvard Business Review, Vol. 56 (3), (1978), pp. 95-102.

15. Hamermesh, R.G., \& Silk, S. "How to Compete in Stagnant Industries." In Hamermesh, R.G. (Ed.), Strategic Management, Wiley \& Sons: New York: NY (1983), pp. 139-150.

16. Harrigan, K.R. Strategies for Declining Businesses, Lexington Books: Lexington, MA (1980).

17. Harrigan, K.R. "Research Methodologies for Contingency Approaches to Business Strategy." Academy of Management Review, Vol. 8, (1983), pp. 398-405.

18. Hatten, K.J. "Strategic Models in the Brewing Industry." Unpublished doctoral dissertation, Purdue University (1974). 
19. Hith, M.A., Ireland, R.D., \& Palia, K.A. "Industrial Firms' Grand Strategy and Functional Importance: Moderating Effects of Technology and Uncertainty." Academy of Management Journal, Vol. 25 (1982), pp. 265-298.

20. Hitt, M.A., Ireland, R.D., \& Stadter, G. "Functional Importance and Company Performance: Moderating Effects of Grand Strategy and Industry Type." Strategic Management Journal, Vol. 3 (1982), pp. 315-330.

21. Hitt, M.A., \& Ireland, R.D. "Corporate Distinctive Competence and Performance: Effects of Perceived Environmental Uncertainty (PEU), Size, and Technology." Decision Sciences, Vol. 15 (1984), pp. 324-349.

22. Hitt, M.A., \& Ireland, R.D. “Corporate Distinctive Competence, Strategy, Industry, and Performance.” Strategic Management Journal, Vol. 6 (1985), pp. 273-293.

23. Hofer, C.W. "Some Preliminary Research on Patterns of Strategic Behavior." Academy of Management Proceedings (1973), pp. 46-54.

24. Hofer, C.W. "Toward a Contingency Theory of Business Strategy." Academy of Management Journal, Vol. 18 (1975), pp. 784-810.

25. Hofer, C.W. “ROVA: A New Measure for Assessing Organizational Performance." In Lamb, R. (Ed.), Advances in Strategic Management, Vol. 2 (1983), pp. 43-55.

26. Hofer, C.W., \& Charan, R. "The Transition to Professional Management: Mission Impossible?" American Journal of Small Business, Vol. 9 (1), (1984), pp. 1-11.

27. Hofer, C.W., \& Schendel, D.E. Strategy Formulation: Analytical Concepts, West: St. Paul, MN (1978).

28. Lenz, R.T. "Strategic Capability: A Concept and Framework for Analysis." Academy of Management Review, Vol. 5 (1980), pp. 225-234.

29. Miller, R. "Strategic Pathways to Growth in Retailing." Journal of Business Strategy, Vol. 1 (3) (1981), pp. 16-29.

30. Mintzberg, H. "Patterns in Strategy Formulation." Management Science, Vol. 24 (1978), pp. 934-948.

31. Ohmae, K. The Mind of the Strategist, Penguin: New York, NY (1982).

32. Porter, M.E. Competitive Strategy: Techniques for Analyzing Industries and Competitors, Free Press: New York, NY (1980).

33. Porter, M.E. Competitive Advantage: Creating and Sustaining Superior Performance, Free Press: New York, NY (1985). 
34. Quinn, J.B. Strategies for Change: Logical Incrementalism, Irwin: Homewood, IL (1980).

35. Rothschild, W.E. How to Gain (and Maintain) the Competitive Advantage, McGrawHill: New York, NY (1984).

36. Rumelt, R.P. "Evaluation of Strategy: Theory and Models." In Schendel, D.E., \& Hofer, C.W. (Eds.), Strategic Management: A New View of Business Policy and Planning, Little, Brown: Boston, MA (1979).

37. Sandberg, W.R. New Venture Performance: The Role of Strategy and Industry Structure, Lexington Books: Lexington, MA (1986).

38. Schendel, D.E., \& Hofer, C.W. Strategic Management: A New View of Business Policy and Planning, Little, Brown: Boston, MA (1979).

39. Schendel, D.E., Patton, G.R., \& Riggs, J. “Corporate Turnaround Strategies: A Study of Profit Decline and Recovery." Jourmal of General Management, Vol. 3 (1976), pp. 3-11.

40. Selznick, P. Leadership in Administration: A Sociological Interpretation, Harper \& Row: New York, NY (1957).

41. Snow, C.C., \& Hrebiniak, L.G. "Strategy, Distinctive Competence, and Organizational Performance." Administrative Science Ouarterly, Vol. 25 (1980), pp. 317-336.

42. Soukup, W. "Strategic Responses to Technological Threats." Unpublished doctoral dissertation, Purdue University (1979).

43. Sousa de Vasconcellos E Sa, J.A., \& Hambrick, D.C. "Key Success Factors: Test of a General Theory in the Mature Industrial Products Sector." Strategic Management Journal, Vol. 10 (1989), pp. 367-382.

44. Stevenson, H.H. "Defining Corporate Strengths and Weaknesses: An Exploratory Study." Unpublished doctoral dissertation, Harvard Business School (1968).

45. Thietart, R.A, \& Vivas, R. "An Empirical Investigation of Success Strategies for Businesses Along the Product Life Cycle." Management Science, Vol. 30 (1984), pp. 1405-1423.

46. Tilles, S. "How to Evaluate Corporate Strategy." Harvard Business Review, Vol. 41 (4), (1963), pp. 111-121.

47. White, R.E. 1986. "Generic Business Strategies, Organizational Context and Performance: An Empirical Investigation.” Strategic Management Journal, Vol. 7 (1986), pp. 217-231.

48. White, R.E., \& Hamermesh, R.G. Toward a Model of Business Unit Economic Performance. Academy of Manarement Review, Vol. 6 (1981), pp. 213-223.

49. Willard, G.E., \& Cooper, A.C. "Survivors of Industry Shakeouts: The Case of the U.S. Color Television Set Industry. Strategic Management Journal, Vol. 6 (1985), pp. 299-318.

50. Woo, C., \& Cooper, A.C. "The Surprising Case for Low Market Share." Harvard Business Review, Vol. 60 (6), (1982), pp. 106-113. 